\title{
Effect of Small-Scale Variations in Environmental Factors on the Distribution of Woody Species in Tropical Deciduous Forests of Vindhyan Highlands, India
}

\author{
R. K. Chaturvedi, ${ }^{1}$ A. S. Raghubanshi, ${ }^{2}$ and J. S. Singh ${ }^{1}$ \\ ${ }^{1}$ Ecosystems Analysis Laboratory, Department of Botany, Banaras Hindu University, Varanasi 221005, India \\ ${ }^{2}$ Institute of Environment and Sustainable Development, Banaras Hindu University, Varanasi 221005, India \\ Correspondence should be addressed to R. K. Chaturvedi, ravikantchaturvedi10@gmail.com
}

Received 9 July 2011; Accepted 22 September 2011

Academic Editor: Guang Sheng Zhou

Copyright ( $) 2011$ R. K. Chaturvedi et al. This is an open access article distributed under the Creative Commons Attribution License, which permits unrestricted use, distribution, and reproduction in any medium, provided the original work is properly cited.

\begin{abstract}
The aim of this study is to investigate the changes in the composition of mature, naturally established and unmanaged TDF in response to small-scale variations in environmental factors. All woody species with a minimum circumference of $10 \mathrm{~cm}$ at $1.37 \mathrm{~m}$ height were surveyed in forty-five $20 \times 50 \mathrm{~m}$ plots distributed over 5 sites in the TDF of Vindhyan highlands, India. Cluster analysis identified two distinct groups of plots. Group 1 plots had higher soil moisture content (SMC), clay, organic C, total N, total P, and light attenuation than group 2 plots. A total of 48 native species belonging to 25 families were encountered in the sampled area. High eigenvalues for the first two Canonical Correspondence Analysis (CCA) axes indicated the occurrence of species in distinct groups, and significant correlations of the axes with environmental variables indicated the effect of these variables on species grouping. In conclusion, patchiness in the soil resources needs to be considered in restoration efforts. The results of this study are expected to facilitate the decision regarding choice of species in afforestation programmes for restoring the TDF.
\end{abstract}

\section{Introduction}

Tropical forests cover about $30 \%$ of the world's land area and $50 \%$ of the world's forested area which is around 4 billion ha $[1,2]$. The dominant vegetation type in tropical forests is the tropical dry forest (TDF) which occupies $42 \%$ of the tropical forest area [3]. In India, the share of TDF is $38.2 \%$ of the total forest cover [4]. According to Singh et al. [5], the TDF is continuously decreasing in the Vindhyan region and the remnant forest cover exists in the form of noncontiguous patches of varying sizes dominated by single or mixed species. The study of change detection using satellite images (1982-1989) of a part of Vindhyan hills identified only $31 \%$ of the forested area which remained unchanged since 1982. About $40 \%$ of the total forest area was converted from mixed forest with crown cover $>50 \%$ to mixed forest with crown cover $30-<50 \%$. The rate of conversion from good to poor forest was $6.6 \%$ of the forested area each year and savannization in the forest area took place at a rate of $3.3 \%$ per year [6]. This calls for massive restoration efforts through reforestation.

Distribution of plant communities, their species, and structural diversity are highly affected by soil water and soil nutrient status [7]. In environments where soil nutrients are abundant, species allocate more to above-ground parts, have more rapid growth rates, and have higher rates of nutrient uptake per gram of root biomass than species from lownutrient environments [8]. Soil organic carbon (C) is a major constituent of soil organic matter which has a major effect on forest productivity and sustainability by influencing soil chemical and biological properties [9]. According to Tateno and Takeda [10], soil nitrogen is strongly linked with forest structure and tree species distribution. In various reports, phosphorus has been estimated to be the principal nutrient limiting tree growth and productivity in tropical forests [7].

De Souza et al. [11] reported significant effect of small variations in soil fertility parameters on the distribution of trees in a Brazilian deciduous forest. Patchiness in the 
composition of Indian TDF was emphasized by Jha and Singh [12]. However, there was a lack of information on the influence of small-scale variation in the environmental factors on the distribution of the tree species. The aim of this study is to investigate the effect of small-scale variation in selected environmental factors on the composition of mature, naturally established and unmanaged TDF of Vindhyan highlands. To do so, we first applied cluster analysis to separate the experimental plots on the basis of the selected environmental factors. Finally, we investigated the relationship between the mean values of environmental factors and corresponding woody species composition. The results of this study are expected to facilitate the decision regarding choice of species in afforestation programmes for restoring the TDF.

\section{Methods}

2.1. Study Site. The present investigation was conducted in five sites, Hathinala West $\left(24^{\circ} 18^{\prime} 07^{\prime \prime} \mathrm{N}\right.$ and $83^{\circ} 05^{\prime} 57^{\prime \prime} \mathrm{E}, 291$ m.a.s.l.), Gaighat $\left(24^{\circ} 24^{\prime} 13^{\prime \prime} \mathrm{N}\right.$ and $83^{\circ} 12^{\prime} 01^{\prime \prime} \mathrm{E}, 245$ m.a.s.l. $)$, Harnakachar $\left(24^{\circ} 18^{\prime} 33^{\prime \prime} \mathrm{N}\right.$ and $83^{\circ} 23^{\prime} 05^{\prime \prime} \mathrm{E}, 323$ m.a.s.l.), Ranitali $\left(24^{\circ} 18^{\prime} 11^{\prime \prime} \mathrm{N}\right.$ and $83^{\circ} 04^{\prime} 22^{\prime \prime}$ E, 287 m.a.s.l.), and Kotwa $\left(25^{\circ} 00^{\prime} 17^{\prime \prime} \mathrm{N}\right.$ and $82^{\circ} 37^{\prime} 38^{\prime \prime}$ E, 196 m.a.s.l.). Hathinala, Gaighat, Harnakachar, and Ranitali sites are situated in Sonebhadra district and Kotwa in Mirzapur district of Uttar Pradesh. They occupy land area of 2555, 394, 1507, 2118, and 199 ha, respectively. The area experiences tropical monsoon climate with three seasons in a year, namely, summer (April to mid-June), rainy (mid-June to September), and winter (November to February). The months of March and October constitute transition periods, respectively, between winter and summer and between rainy and winter seasons. According to the data collected from the meteorological stations of the state forest department for 1980-2010, The mean annual rainfall ranges from $1196 \mathrm{~mm}$ (Hathinala) to $865 \mathrm{~mm}$ (Kotwa site). About $85 \%$ of the annual rainfall occurs during the monsoon season from the southwest monsoon, and the remaining from the few showers in December and in May-June. There is an extended dry period of about 9 months in the annual cycle [12]. The maximum monthly temperature varies from $20^{\circ} \mathrm{C}$ in January to $46^{\circ} \mathrm{C}$ in June, and the mean minimum monthly temperature reaches $12^{\circ} \mathrm{C}$ in January and $31^{\circ} \mathrm{C}$ in May.

2.2. Data Collection. At each site, nine plots, each of $1000 \mathrm{~m}^{2}$ $(50 \times 20 \mathrm{~m})$ were selected at random for sampling vegetation and soil. Plots were randomly selected to reduce bias caused by within-site differences in soil conditions. Rectangular plots were used because most plant distributions are clumped, and a rectangle can best encompass patches of different species [13]. Further, rectangular quadrats may survey heterogeneity better than square quadrats [14]. The size was decided on the basis of species area curve [15]. In each plot, all woody species with a minimum circumference of $10 \mathrm{~cm}$ at $1.37 \mathrm{~m}$ height were identified, counted, and measured for basal area. Plant nomenclature was based on
"Flora of Madhya Pradesh" 1997 (eds. Mudgal V, Khanna KK, Hajra PK) Botanical Survey of India, Calcutta, India. Soil moisture content (SMC) was measured as percentage by volume by theta probe instrument (type ML 1, Delta-T devices, Cambridge, England) at 10 random locations from all plots. Composite surface soil $(0-10 \mathrm{~cm})$ samples were also collected from those locations for chemical analysis. These samples were analysed for texture following Sheldrick and Wang [16]. Analyses of soil samples were also carried out for C [17], total nitrogen (N) [18], and total phosphorus (P) [19] contents. Light attenuation (L) in each plot was measured with a digital lux meter (Lutron LX 101 Lux Meter). It was calculated as follows:

\section{Light attenuation}

$$
\begin{aligned}
= & \frac{\text { Light intensity in open }- \text { Light intensity under canopy }}{\text { Light intensity in open }} \\
& \times 100 \text {. }
\end{aligned}
$$

Light attenuation is a surrogate for canopy cover; the higher the attenuation, the lower the solar radiation incident on the soil surface and, hence, its effects on SMC.

2.3. Data Analyses. Cluster analysis was performed using the PC-ORD 5 program [20] to identify groups among the sampling plots based on soil physiochemical properties and L. The euclidean distance was used for cluster analysis.

The importance value index (IVI) of each species, was calculated as the sum of relative density, relative frequency, and relative basal area [15]. Species richness [21], species evenness [22], Shannon-Wiener diversity index [23], and Simpson's index [24] were also calculated. $\beta$-diversity was calculated according to Whittaker [22].

Canonical Correspondence Analysis (CCA) was performed by using the PC-ORD 5 program [20] to correlate environmental variables and vegetation variables [11]. Density data for tree and shrub species were used for the construction of main matrix, and environmental variables were selected as second matrix.

\section{Results}

3.1. Environmental Variables. A cluster analysis based on the soil properties and $\mathrm{L}$ of the 45 experimental plots showed two distinct groups (Figure 1). Group 1 consisted of 20 plots (1 to 9 plots of Hathinala; 16 to 18 plots of Gaighat; 19, 20, and 25 to 27 of Harnakachar; 28, 35, and 36 of Ranitali). Group 2 consisted of the remaining 25 plots (10 to 15 of Gaighat; 21 to 24 of Harnakachar; 29 to 34 of Ranitali; 37 to 45 of Kotwa). All the plots of Hathinala were placed in group 1, and all the plots of Kotwa were categorized in group 2 showing a very high difference in environmental variables between the two sites. The largest variation between the two groups was in $\mathrm{P}$, the mean value for group $1(0.04 \%)$ being more than five times the mean value for group $2(0.006 \%)$ (Figure 2). Significant differences were found in SMC, clay, silt, rockiness, $\mathrm{C}, \mathrm{N}, \mathrm{P}$, and $\mathrm{L}$ between the two groups; 


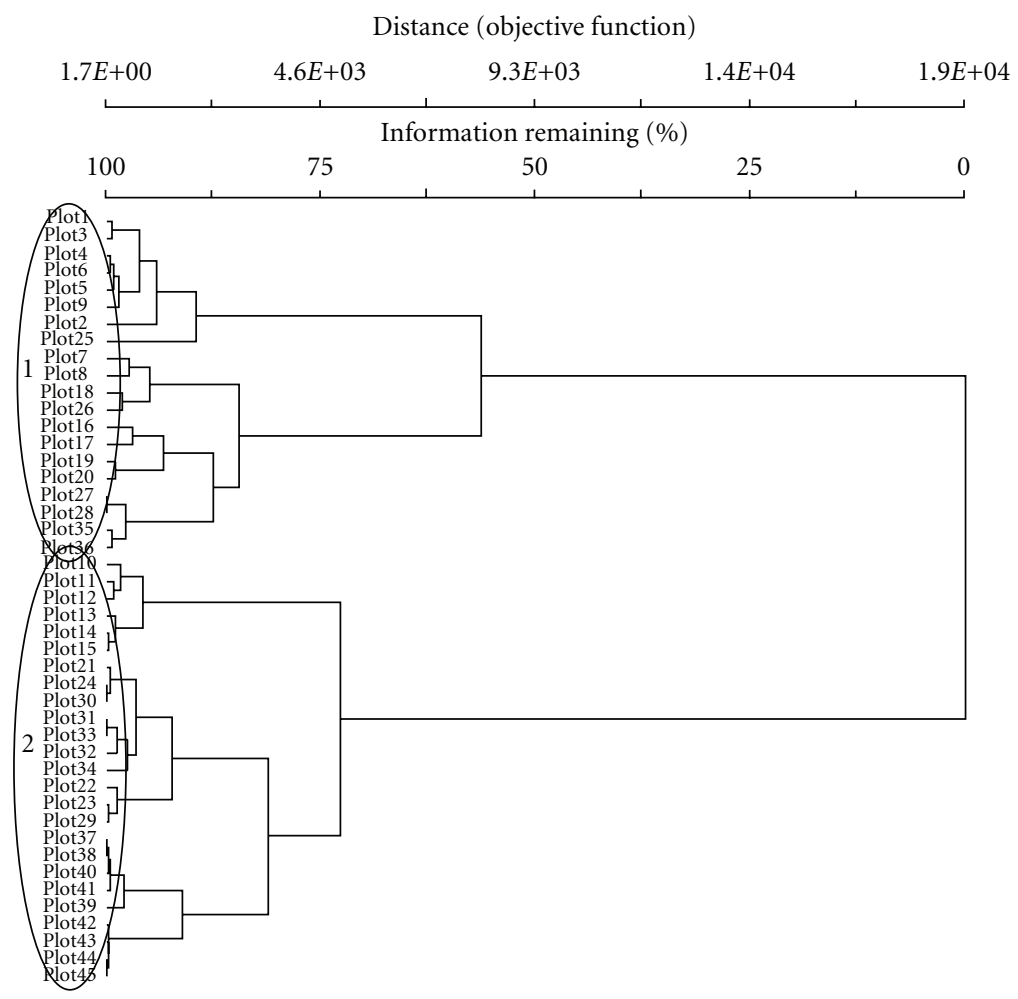

FIGURE 1: Hierarchical classification of the 45 sampling plots in the forests of Vindhyan highlands based on cluster analysis of some selected environmental variables. Group 1 with 20 plots had high levels of soil moisture, clay, silt, organic C, total N, total P, and canopy light attenuation, and Group 2 with 25 plots had high levels of rockiness and low levels of soil moisture, clay, silt, organic C, total N, total P, and canopy light attenuation.

however, there was no significant difference in sand content (Figure 2).

3.2. Phytosociological Survey. A total of 4, 680 individuals belonging to 48 species and 25 families were encountered in the 45 experimental plots with a total area of 4.5 ha (Table 1 ). Leguminosae (10), Rubiaceae (5), Anacardiaceae (3), Combretaceae (3), Euphorbiaceae (3), and Rhamnaceae (3) were the families with the largest number of species. Of the 48 species, 30 were common to both groups, whereas 13 were exclusive to group 1 and 5 to group 2 . The species that scored maximum IVI in group 1 was Terminalia tomentosa and in group 2 Dendrocalamus strictus (Table 1). The most important species in both of the groups were Terminalia tomentosa, Shorea robusta, Diospyros melanoxylon, Buchanania lanzan, Lagerstroemia parviflora, Soymida febrifuga, Anogeissus latifolia, and Acacia catechu. These species accounted for $62 \%$ of the total IVI in group 1 and $48 \%$ in group 2 (Table 1). Bridelia retusa, Adina cordifolia, Bauhinia racemosa, Pterocarpus marsupium, Gardenia turgida, Semecarpus anacardium, Mitragyna parvifolia, Grewia serrulata, Cassia fistula, Ougeinia oogenesis, Schleichera oleosa, Terminalia chebula, and Albizia odoratissima were exclusive to group 1, whereas Abrus precatorius, Dendrocalamus strictus, Ficus racemosa, Lantana camara, and Sterculia urens were exclusive to group 2. In group 1 , there were 22 species per ha, whereas group
2 consisted of 14 species per ha (Table 2). Margalef's species richness and Whittaker's species evenness were also greater in group 1 compared to group 2; whereas $\beta$-diversity was maximum in group 2 compared to group 1 (Table 2 ). Shannon-Wiener index did not differ significantly between the two groups (Table 2); however, site-level differences were significant and the index ranged from 1.48 at Kotwa to 2.52 at Hathinala. The distribution of tree circumference varied significantly between the two groups for the individuals having stem circumference less than $90 \mathrm{~cm}$ (Figure 3). The number of stems having circumference less than $90 \mathrm{~cm}$ was fewer in group 2 compared to group 1 (Figure 3 ).

3.3. Relationships between Tree Communities and Soil Properties. Results of canonical correspondence analysis using the density data for all species and soil properties and $\mathrm{L}$ as environmental variables are presented in Figure 4. Eigenvalues for CCA axes 1, 2, and 3 were $0.443,0.294$, and 0.159 , respectively, and the species environment correlations for the axes were $0.889,0.870$, and 0.775 , respectively. High eigenvalues for the first two axes indicated the occurrence of species in distinct groups [25], and significant correlations of the axes with environmental variables indicated the effect of these variables on species grouping (Table 3 ). First axis showed significant positive correlation with SMC $(r=0.83$, $n=45)$, total $\mathrm{N}(r=0.41, n=45), \mathrm{P}(r=0.68, n=45)$, clay 

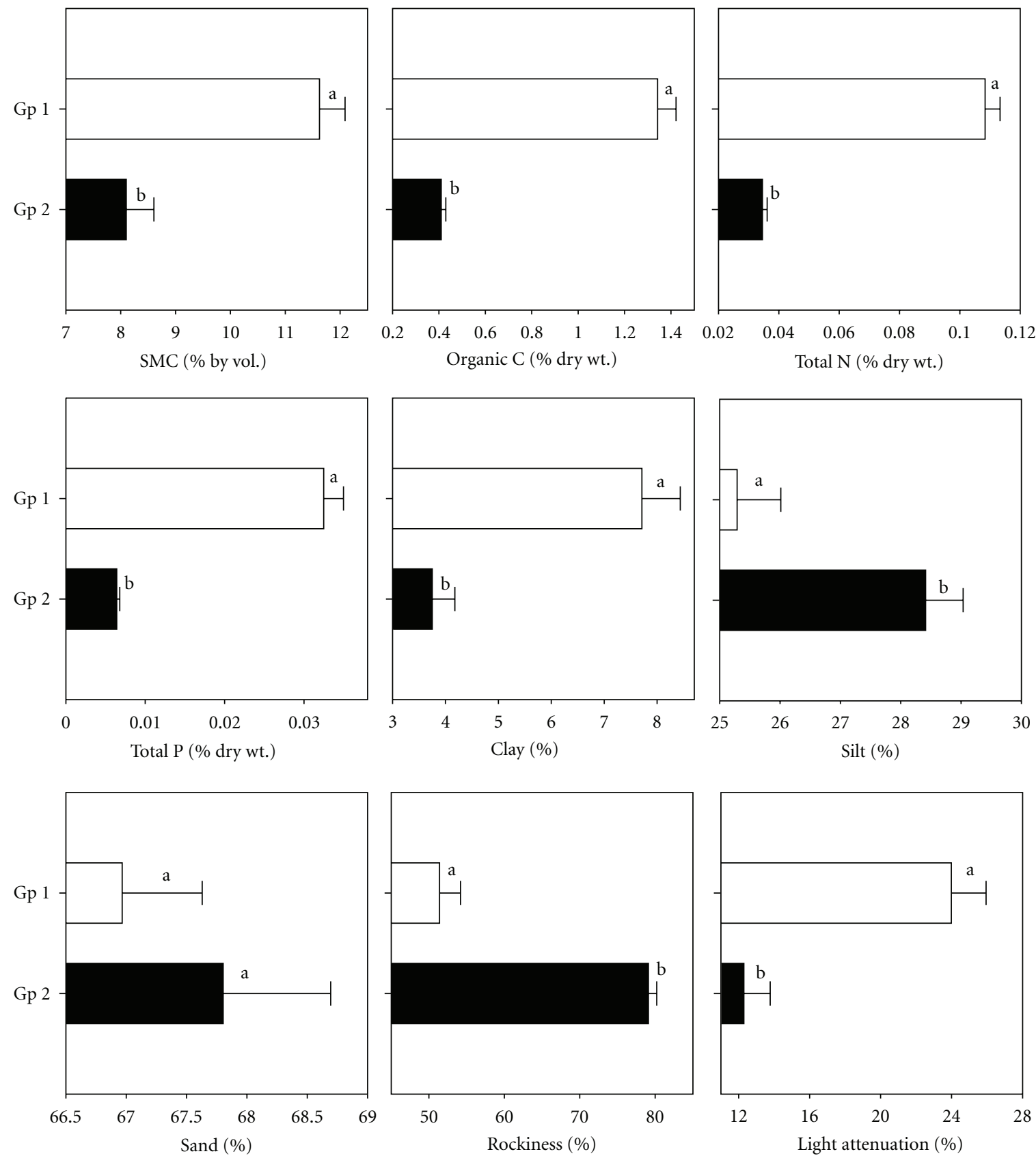

Figure 2: Chemical characteristics of the two groups of experimental plots in the forests of Vindhyan highlands separated on the basis of the selected environmental variables. Means of the same environmental variable followed by the different case letters significantly differ between themselves.

( $r=0.75, n=45)$, and $\mathrm{L}(r=0.82, n=45)$ and negative with sand $(r=-0.50, n=45)$ and rockiness $(r=-0.46$, $n=45)$. Second axis showed significant positive associations with $\mathrm{P}(r=0.64, n=45)$ and sand $(r=0.50, n=45)$ and negative with silt $(r=-0.67, n=45)$ and rockiness ( $r=-0.33, n=45)$. Third axis was positively correlated with silt $(r=0.65, n=45)$ and rockiness $(r=0.60, n=45)$ and negatively with $\mathrm{C}(r=-0.66, n=45), \mathrm{N}(r=-0.59$, $n=45)$, sand $(r=-0.47, n=45)$, and $\mathrm{L}(r=-0.38$, $n=45)$.
Adina cordifolia, Albizia odoratissima, Bauhinia racemosa, Bridelia retusa, Cassia fistula, Flacourtia indica, Gardenia latifolia, Grewia serrulata, Miliusa tomentosa, Mitragyna parvifolia, Ougeinia oogenesis, Pterocarpus marsupium, Schleichera oleosa, Schrebera swietenioides, Semecarpus anacardium, Shorea robusta, Terminalia chebula, and Terminalia tomentosa were more frequent in plots with high SMC, clay, N, P, and L (upper left quadrant in Figure 4). Carissa spinarum, Dendrocalamus strictus, Ficus racemosa, Holarrhena antidysenterica, Nyctanthes arbor-tristis, Zizyphus glaberrima, and Zizyphus 
TABLE 1: Occurrence of woody species of Vindhyan highlands in two groups of experimental plots separated on the basis of some selected environmental variables.

\begin{tabular}{|c|c|c|c|c|c|}
\hline \multirow{2}{*}{ Species } & \multirow{2}{*}{ Family } & \multicolumn{2}{|c|}{ Group 1} & \multicolumn{2}{|c|}{ Group 2} \\
\hline & & $\mathrm{N}$ & IVI & $\mathrm{N}$ & IVI \\
\hline Terminalia tomentosa (Roxb.) Wight \& Arn. & Combretaceae & 335 & 10.2 & 133 & 5.80 \\
\hline Shorea robusta Gaertn. f. & Dipterocarpaceae & 324 & 9.82 & 196 & 7.39 \\
\hline Diospyros melanoxylon Roxb. & Ebenaceae & 322 & 8.45 & 176 & 6.56 \\
\hline Buchanania lanzan Spreng. & Anacardiaceae & 199 & 7.44 & 136 & 5.71 \\
\hline Lagerstroemia parviflora Roxb. & Lythraceae & 249 & 7.23 & 203 & 8.20 \\
\hline Soymida febrifuga A. Juss. & Meliaceae & 211 & 6.51 & 101 & 3.89 \\
\hline Anogeissus latifolia (Roxb. ex DC.) Wall. ex Guill. \& Perr. & Combretaceae & 188 & 6.28 & 101 & 4.67 \\
\hline Acacia catechu (L.) Willd. & Mimosaceae & 220 & 6.01 & 134 & 5.35 \\
\hline Hardwickia binata Roxb. & Caesalpiniaceae & 120 & 4.41 & 33 & 1.83 \\
\hline Bridelia retusa (L.) A. Juss. & Euphorbiaceae & 47 & 2.34 & 0 & 0 \\
\hline Holarrhena antidysenterica Wall. & Apocynaceae & 81 & 2.28 & 86 & 3.30 \\
\hline Boswellia serrata Triana. \& Planch. & Burseraceae & 16 & 2.24 & 2 & 0.46 \\
\hline Gardenia latifolia Aiton. & Rubiaceae & 64 & 2.06 & 3 & 0.43 \\
\hline Adina cordifolia (Roxb.) Ridsdale. & Rubiaceae & 57 & 2.02 & 0 & 0 \\
\hline Miliusa tomentosa (Roxb.) J. Sinclair. & Annonaceae & 28 & 1.84 & 5 & 0.59 \\
\hline Emblica officinalis Gaertn. & Euphorbiaceae & 9 & 1.71 & 16 & 1.55 \\
\hline Lannea coromandelica $\mathrm{L}$. & Anacardiaceae & 14 & 1.62 & 40 & 3.34 \\
\hline Flacourtia indica Merr. & Flacourtiaceae & 30 & 1.61 & 14 & 1.35 \\
\hline Zizyphus glaberrima Satap. & Rhamnaceae & 23 & 1.59 & 57 & 2.71 \\
\hline Bauhinia racemosa Lam. & Caesalpiniaceae & 30 & 1.42 & 0 & 0 \\
\hline Madhuca longifolia (J.König ex L.) J.F.Macbr. & Sapotaceae & 23 & 0.93 & 16 & 0.86 \\
\hline Zizyphus oenoplea Mill. & Rhamnaceae & 21 & 0.92 & 37 & 2.14 \\
\hline Cassia siamea Lam. & Caesalpiniaceae & 28 & 0.87 & 1 & 0.15 \\
\hline Acacia auriculiformis A.Cunn. ex Benth. & Mimosaceae & 30 & 0.85 & 30 & 1.19 \\
\hline Zizyphus nummularia Wight and Am. & Rhamnaceae & 10 & 0.81 & 8 & 0.89 \\
\hline Nyctanthes arbor-tristis Linn. & Oleaceae & 31 & 0.78 & 92 & 2.96 \\
\hline Pterocarpus marsupium Roxb. & Fabaceae & 11 & 0.74 & 0 & 0 \\
\hline Gardenia turgida Roxb. & Rubiaceae & 7 & 0.74 & 0 & 0 \\
\hline Elaeodendron glaucum (Rottb.) Pers. & Celastraceae & 7 & 0.73 & 5 & 0.94 \\
\hline Holoptelea integrifolia (Roxb.) Planch. & Ulmaceae & 6 & 0.67 & 2 & 0.29 \\
\hline Semecarpus anacardium L.f. & Anacardiaceae & 23 & 0.66 & 0 & 0 \\
\hline Mitragyna parvifolia (Roxb.) Korth. & Rubiaceae & 15 & 0.62 & 0 & 0 \\
\hline Grewia serrulata DC. & Tiliaceae & 7 & 0.53 & 0 & 0 \\
\hline Cassia fistula $\mathrm{L}$ & Fabaceae & 15 & 0.47 & 0 & 0 \\
\hline Carissa spinarum $\mathrm{L}$. & Apocynaceae & 6 & 0.44 & 7 & 0.85 \\
\hline Woodfordia fruticosa (L.) Kurz. & Lythraceae & 8 & 0.43 & 33 & 1.73 \\
\hline Ougeinia oogenesis Hochreut. & Leguminosae & 4 & 0.37 & 0 & 0 \\
\hline Schrebera swietenioides Roxb. & Oleaceae & 9 & 0.34 & 3 & 0.29 \\
\hline Schleichera oleosa (Lour.) Oken. & Sapindaceae & 6 & 0.31 & 0 & 0 \\
\hline Hymenodictyon excelsum (Roxb.) Wall. in Roth. & Rubiaceae & 2 & 0.24 & 4 & 0.44 \\
\hline Terminalia chebula Retz. & Combretaceae & 1 & 0.17 & 0 & 0 \\
\hline Azadirachta indica A. Juss. & Meliaceae & 1 & 0.17 & 3 & 0.62 \\
\hline Albizia odoratissima Roxb. & Mimosaceae & 2 & 0.14 & 0 & 0 \\
\hline Abrus precatorius $\mathrm{L}$. & Fabaceae & 0 & 0 & 18 & 1.08 \\
\hline Dendrocalamus strictus (Roxb.) Nees. & Poaceae & 0 & 0 & 104 & 20.07 \\
\hline Ficus racemosa Linn. & Moraceae & 0 & 0 & 37 & 1.79 \\
\hline Lantana camara L. & Verbenaceae & 0 & 0 & 1 & 0.14 \\
\hline Sterculia urens Roxb. & Sterculiaceae & 0 & 0 & 3 & 0.47 \\
\hline
\end{tabular}




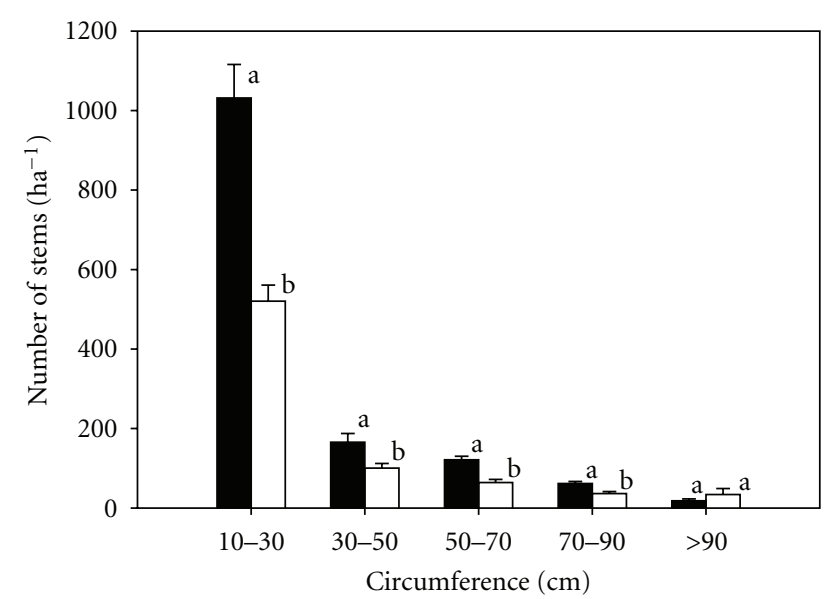

Group 1

FIGURE 3: Distribution of tree circumference in the two groups of experimental plots in the forests of Vindhyan highlands separated on the basis of the selected environmental variables.

TABLE 2: Average values of the phytosociological parameters in the two groups of experimental plots separated on the basis of the selected environmental variables.

\begin{tabular}{lcc}
\hline Parameters & Group 1 & Group 2 \\
\hline Total number of species & 43 & 35 \\
Number of species per ha & 22 & 14 \\
Number of exclusive species & 13 & 5 \\
Number of stems per ha & 14200 & 7360 \\
Species richness (Margalef) & 5.28 & 4.65 \\
Species evenness (Whittaker) & 7.40 & 6.78 \\
Shannon-Wiener index & 2.94 & 2.94 \\
Simpson's index & 0.07 & 0.07 \\
Beta diversity & 2.67 & 3.14 \\
\hline
\end{tabular}

TABLE 3: Results of the canonical correspondence analysis for the distribution of woody species of Vindhyan highlands. Total variance $=2.2073$.

\begin{tabular}{lrcc}
\hline & Axis 1 & Axis 2 & Axis 3 \\
\hline Eigenvalue & 0.443 & 0.294 & 0.159 \\
Species-environment correlation & 0.889 & 0.870 & 0.775 \\
Cumulative percentage of variance for species & 20.1 & 33.4 & 40.6 \\
Species-environment variance & 20.1 & 13.3 & 7.2 \\
\hline
\end{tabular}

oenoplea were dominant in plots with high rockiness and sand content (Figure 4). Abrus precatorius, Acacia auriculiformis, Anogeissus latifolia, Azadirachta indica, Buchanania lanzan, Cassia siamea, Diospyros melanoxylon, Elaeodendron glaucum, Emblica officinalis, Lagerstroemia parviflora, Lannea coromandelica, Lantana camara, and Woodfordia fruticosa were associated with rocky soil with high silt content. Acacia catechu, Boswellia serrata, Gardenia turgida, Hardwickia binata, Holoptelea integrifolia, Hymenodictyon excelsum, Soymida febrifuga, and Zizyphus nummularia were abundantly present in plots with high C, N, sand, and L.

\section{Discussion}

There was significant difference in SMC in the studied plots of the two groups. Group 1 having high SMC also had greater C, N, P, clay, and L compared to group 2, which had greater silt and rockiness. According to Yang et al. [26], high SMC lowers the rate of organic matter decomposition, which increases $\mathrm{C}$ in soils having high moisture content. Yang et al. [27] have also stressed the importance of $\mathrm{C}$ and $\mathrm{N}$ in structuring the diversity of desert riparian forest of China. Nitrogen mineralization [28] and P availability [29] in soil have also been reported to increase at high SMC. Clay-rich soils have greater availability of water at the surface compared to sand-rich soils where water availability to plants is at greater depths [30]. Clay-rich soils are normally also rich in soil organic matter [31]. According to Lowman [32], L is also predicted to vary according to canopy density and structure.

The number of species in semideciduous forests $(50$ $70)$ and rainforests $(100-150)$ is greater than in tropical deciduous forests [33]. In tropical deciduous forests, species richness is significantly lower due to anthropogenic disturbances, such as burning, grazing, and wood collection [34]. The species diversity is also low in these forests, and only few species show high dominance [35]. According to Gentry [33], the common species in these forests are generally concentrated in few important families, and it is assumed that the abundance of species is mostly governed by ecological factors rather than nonequilibrium chancebased dynamics [11]. Forest structure and species diversity have been widely studied in various regions of the tropics (e.g., [36-41]). Gentry [42] recorded 275-283 tree species $\mathrm{ha}^{-1}$ for trees $\geq 10 \mathrm{~cm}$ in diameter at breast height (DBH) at Yanamono and Mishana near Iquitos, Peru. Valencia et al. [43] enumerated 307 species ha ${ }^{-1}$ for the same DBH in Amazonian Ecuador. These figures formed the world highest record of tree species on a hectare basis for stem $\geq 10 \mathrm{~cm} \mathrm{DBH} \mathrm{[37].} \mathrm{A} \mathrm{direct} \mathrm{comparison} \mathrm{of} \mathrm{tree} \mathrm{inventories}$ across tropical forests is difficult due to lack of uniformity in the criteria considered and method employed. In the present study, 48 species were enumerated in the Vindhyan dry tropical forest within the 4.5 ha area for woody species $\geq 10 \mathrm{~cm}$ circumference. The values reported from other large-scale permanent plot inventories (for trees $\geq 10 \mathrm{~cm}$ $\mathrm{DBH}$, i.e., $\geq 31.4 \mathrm{~cm}$ circumference) were as follows: 37 species in Kampong Thom province, Cambodia [44]; 49 species in Vindhyan dry tropical forest, India [45]; 996 species in 52 ha plot of Lambir Hills National Park, Malaysia [46]; 660 species in a 50 ha plot of Pasoh Forest reserve, Malaysia [47]; 229 species in a 50 ha plot in Barro Colorado Island, Panama [48]; 146 species in a 30 ha plot at Varagaliar, Anamalais, Western Ghat, India [37]; 164 species in a 25 ha plot of Sinharaja Biosphere Reserve, Sri Lanka [46].

For tree species having $\geq 10 \mathrm{~cm} \mathrm{DBH}$, Top et al. [44] found a basal area of $23 \mathrm{~m}^{2} \mathrm{ha}^{-1}$ in Kampong Thom province, Cambodia, and Backéus et al. [49] reported 3.9 to $16.7 \mathrm{~m}^{2} \mathrm{ha}^{-1}$ in Miombo woodlands, Tanzania. Chittibabu and Parthasarathy [50] recorded $23 \mathrm{~m}^{2} \mathrm{ha}^{-1}$ in a highly disturbed site of Mottukkadu Shola and $54 \mathrm{~m}^{2} \mathrm{ha}^{-1}$ in an undisturbed site at Perumakkai Shola, Kolli hills, Eastern Ghats, 


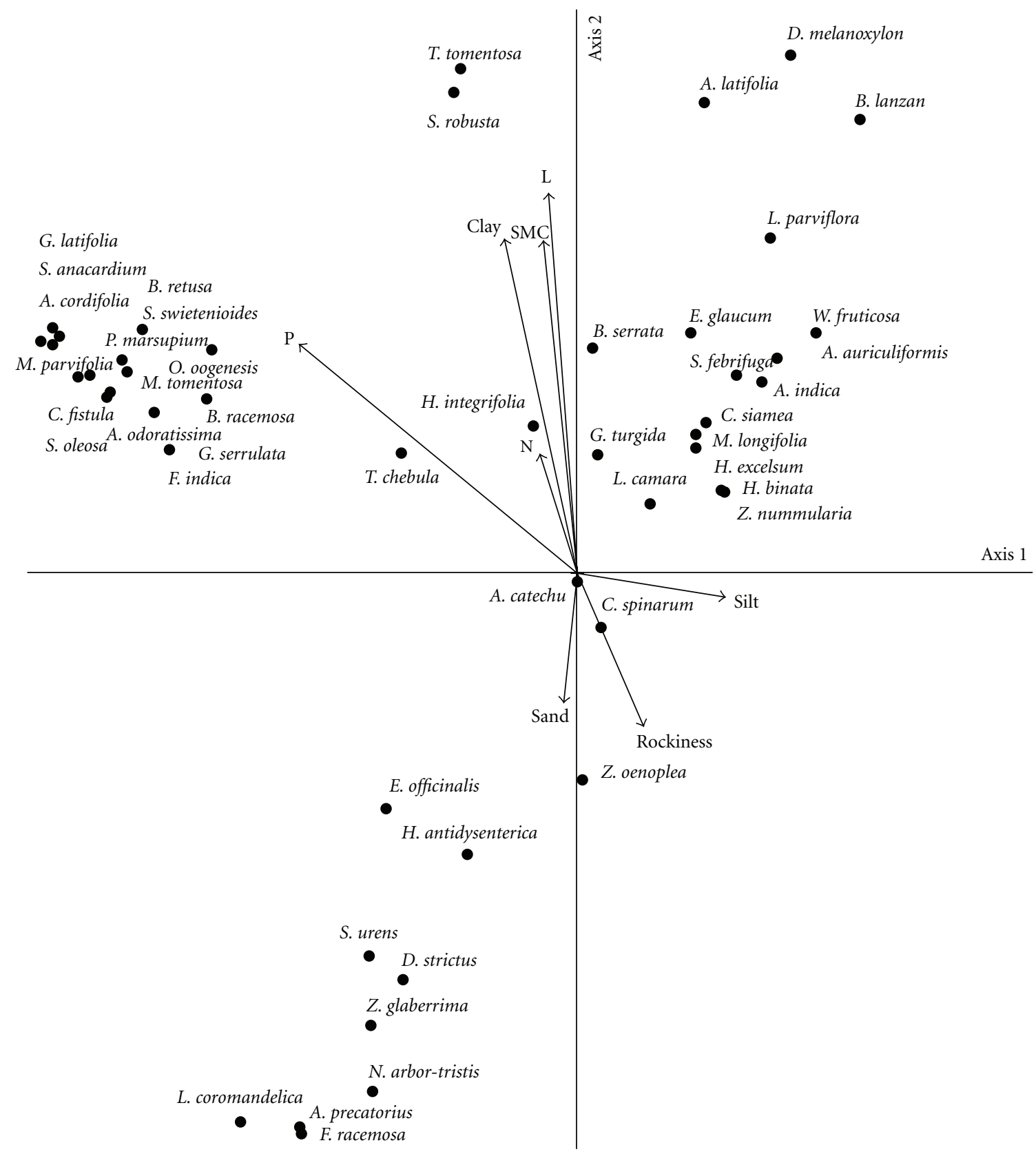

FIGURE 4: Ordination of the woody species in the forests of Vindhyan highlands by canonical correspondence analysis. SMC: soil moisture content; N: total nitrogen; P: total phosphorus; L: light attenuation.

India. In Vindhyan dry tropical forest, India, Sagar and Singh [51] reported 1.31 to $13.8 \mathrm{~m}^{2} \mathrm{ha}^{-1}$ tree basal area in the five locations. In this study, we report a range of $3.1 \mathrm{~m}^{2} \mathrm{ha}^{-1}$ at the driest site Kotwa to $18.0 \mathrm{~m}^{2} \mathrm{ha}^{-1}$ at the moist site Hathinala for woody species having $\geq 10 \mathrm{~cm}$ circumference. In the two groups, the mean value was $14.3 \mathrm{~m}^{2} \mathrm{ha}^{-1}$ for group 1 and $13.3 \mathrm{~m}^{2} \mathrm{ha}^{-1}$ for group 2 .

The most species-rich family in this study is Leguminosae, and it is also reported by Gentry [33] as a common family in tropical dry forests. Singh et al. [52] and Sagar et al. [45] have reported Acacia catechu, Anogeissus latifolia, Diospyros melanoxylon, Lagerstroemia parviflora, and
Hardwickia binata as the most frequent tree species in Vindhyan highlands, and, according to Sagar et al. [45], Shorea robusta is the characteristic species of Hathinala site. The low Shannon-Wiener index for both Groups in this study reflects higher dominance of few species (Terminalia tomentosa, Shorea robusta, Diospyros melanoxylon, Buchanania lanzan, and Lagerstroemia parviflora). Sagar et al. [53] and Raghubanshi and Tripathi [54] have also reported low Shannon-Wiener index in different tree communities of Vindhyan highlands. According to Martijena and Bullock [55], the greater dominance of few species in a forest shows that its formation has taken place under extreme 
environmental conditions such as shallow soils and low water availability. The lowest Shannon-Wiener index of the driest Kotwa site reflects the dominance of only a few species in the low SMC regime. The significant difference in the distribution of the circumference of woody species in the two groups of plots shows a better regeneration in more moist group 1 plots.

The CCA results in our study showed that the distributional response to small variation in environmental variables differed among the woody species. In other studies, Clark et al. [56] showed the effect of topography and soil properties in the distribution of tree species in a tropical forest of Costa Rica. De Souza et al. [11] analyzed the influence of soil fertility on the distribution of tree species in 1 ha area in a deciduous forest of Brazil and reported that edaphic preferences were not absolute to the extent of determining the presence or absence of a species. Pausas and Austin [57] suggested that, over any large region, the species distribution is likely to be governed by two or more environmental factors and not by a single factor. Russo et al. [58] suggested the demographic responses of the species to resource variations among soil types to play an important role in generating and maintaining the edaphically biased spatial distributions of tree species at Lambir in a Bornean rainforest. In our study involving a total of $4.5 \mathrm{ha}$, the presence or absence of several species was determined by edaphic preferences.

Our study, thus, indicated that small variations in the environmental variables can determine the distribution of woody species resulting into patchiness in the composition of the TDF. While designing the reforestation programmes for the TDF, the response of different species to the patchiness in edaphic resources has to be kept in mind.

\section{Acknowledgments}

The authors thank the Ministry of Environment and Forests, Government of India for the financial support. J. S. Singh is supported under NASI Senior Scientist Scheme.

\section{References}

[1] FAO, "Global forest resources assessment 2000-Main report, FAO Forestry Paper, Vol. 140," Food and Agriculture Organization of the United Nations, Rome, Italy, 2001.

[2] FAO, "FAOSTAT Online Statistical Service," Food and Agriculture Organization of the United Nations (FAO), Rome, Italy, 2008.

[3] L. Galicia, A. E. Zarco-Arista, K. I. Mendoza-Robles, J. L. Palacio-Prieto, and A. García-Romero, "Land use/cover, landforms and fragmentation patterns in a tropical dry forest in the southern Pacific region of Mexico," Singapore Journal of Tropical Geography, vol. 29, no. 2, pp. 137-154, 2008.

[4] MoEF, "National Forestry Action Plan," Ministry of Environment and Forests, Government of India, New Delhi, India, 1999.

[5] J. S. Singh, K. P. Singh, and M. Agrawal, "Environmental degradation of the Obra-Renukoot-Singrauli area, India, and its impact on natural and derived ecosystems," Environmentalist, vol. 11, no. 3, pp. 171-180, 1991.
[6] A. S. Raghubanshi, C. S. Jha, C. B. Pandey, L. Singh, and J. S. Singh, "Effects of forest conversion on vegetation and soil carbon and functional trait of resulting vegetation," in Impact of Global Climate Changes on Photosynthesis and Plant Productivity, Y. P. Abrol, P. N. Wattal, A. Gnanum, D. R. Govindji, and A. H. Ort, Eds., pp. 723-749, Teramura. Oxford and IBH Publishing Company, New Delhi, India, 1991.

[7] P. A. Palmiotto, S. J. Davies, K. A. Vogt, M. S. Ashton, D. J. Vogt, and P. S. Ashton, "Soil-related habitat specialization in dipterocarp rain forest tree species in Borneo," Journal of Ecology, vol. 92, no. 4, pp. 609-623, 2004.

[8] D. Tilman, "On the meaning of competition and the mechanisms of competitive superiority," Functional Ecology, vol. 1, no. 4, pp. 304-315, 1987.

[9] J. Goma-Tchimbakala, "Carbon and nitrogen storage in soil aggregates from different Terminalia superba age plantations and natural forest in Kouilou, Congo," International Journal of Soil Science, vol. 4, no. 4, pp. 104-113, 2009.

[10] R. Tateno and H. Takeda, "Forest structure and tree species distribution in relation to topography-mediated heterogeneity of soil nitrogen and light at the forest floor," Ecological Research, vol. 18, no. 5, pp. 559-571, 2003.

[11] J. P. De Souza, G. M. Araújo, and M. Haridasan, "Influence of soil fertility on the distribution of tree species in a deciduous forest in the Triângulo Mineiro region of Brazil," Plant Ecology, vol. 191, no. 2, pp. 253-263, 2007.

[12] C. S. Jha and J. S. Singh, "Compositions and dynamics of dry tropical forest in relation to soil texture," Journal of Vegetation Science, vol. 1, no. 5, pp. 609-614, 1990.

[13] K. A. Kershaw, Quantitive and Dynamic Ecology, Edward Arnold, London, UK, 1964.

[14] G. C. Reese, K. R. Wilson, J. A. Hoeting, and C. H. Flather, "Factors affecting species distribution predictions: a simulation modeling experiment," Ecological Applications, vol. 15, no. 2, pp. 554-564, 2005.

[15] D. Mueller-Dombois and H. Ellenberg, Aims and Methods of Vegetation Ecology, John Wiley \& Sons, NewYork, NY, USA, 1974.

[16] B. H. Sheldrick and C. Wang, "Particle-size distribution," in Soil Sampling and Methods of Analysis, M. R. Carter, Ed., pp. 499-511, Canadian Society of Soil Science, Lewis, Ann Arbor, Mich, USA, 1993.

[17] A. Walkley and I. A. Black, "An examination of the Degtjareff method for determining soil organic matter, and a proposed modification of the chromic acid titration method," Soil Science, vol. 37, no. 7, pp. 29-38, 1934.

[18] J. M. Bremner and C. S. Mulvaney, "Nitrogen-total," in Methods of Soil Analysis: Part 2. Chemical and Microbiological Properties. Agronomy Monograph No. 9, A. L. Page, R. H. Miller, and D. R. Keeney, Eds., pp. 595-924, American Society of Agronomy and Soil Science Society of America, Madison, Wis, USA, 2nd edition, 1982.

[19] S. R. Olsen and L. E. Sommers, "Phosphorus," in Methods of Soil Analysis: Part 2. Chemical and Microbiological Properties. Agronomy Monograph No. 9, A. L. Page, R. H. Miller, and D. R. Keeney, Eds., pp. 403-430, American Society of Agronomy and Soil Science Society of America, Madison, Wis, USA, 2nd edition, 1982.

[20] B. McCune and M. J. Mefford, Multivariate Analysis on the PCORD System, Version 5, MjM Software, Gleneden Beach, Ore, USA, 2005.

[21] R. Margalef, "Information theory in ecology," General Systems, vol. 3, pp. 36-71, 1958, Translated in Royal Academy of Science and Arts, Barcelona, vol. 32, pp. 373-449, 1957. 
[22] R. H. Whittaker, "Evolution and measurement of species diversity," Taxon, vol. 21, no. 2, pp. 213-251, 1972.

[23] C. E. Shannon and W. Weaver, The Mathematical Theory of Communication, University of Illinois Press, Urbana, Ill, USA, 1949.

[24] E. C. Pielou, Mathematical Ecology, Wiley-Interscience, New York, NY, USA, 1977.

[25] C. J. F. Ter Braak, "Ordination," in Data Analysis in Community and Landscape Ecology, H. G. Jongman, C. J. F. Ter Braak, and O. F. R. van Tongeren, Eds., pp. 91-173, Cambridge University Press, Cambridge, UK, 1995.

[26] X. Yang, M. Wang, Y. Huang, and Y. Wang, "A onecompartment model to study soil carbon decomposition rate at equilibrium situation," Ecological Modelling, vol. 151, no. 1, pp. 63-73, 2002.

[27] Y. Yang, J. Fang, P. Smith et al., "Changes in topsoil carbon stock in the Tibetan grasslands between the 1980s and 2004," Global Change Biology, vol. 15, no. 11, pp. 2723-2729, 2009.

[28] G. Stanford and E. Epstein, "Nitrogen mineralization-water relations in soils," Soil Science Society of America Proceedings, vol. 38, pp. 103-107, 1974.

[29] M. Van Oorschot, E. Robbemont, M. Boerstal, I. Van Strien, and M. Van Kerkhoven-Schmitz, "Effects of enhanced nutrient availability on plant and soil nutrient dynamics in two English riverine ecosystems," Journal of Ecology, vol. 85, no. 2, pp. 167179, 1997.

[30] N. B. English, J. F. Weltzin, A. Fravolini, L. Thomas, and D. G. Williams, "The influence of soil texture and vegetation on soil moisture under rainout shelters in a semi-desert grassland," Journal of Arid Environments, vol. 63, no. 1, pp. 324-343, 2005.

[31] D. S. Jenkinson, "The Rothamsted long-term experiments: are they still of use?" Agronomy Journal, vol. 83, no. 1, pp. 2-10, 1991.

[32] M. D. Lowman, "Light interception and its relation to structural differences in three Australian rainforest canopies," Australian Journal of Ecology, vol. 11, no. 2, pp. 163-170, 1986.

[33] A. H. Gentry, "Diversity and floristic composition of neotropical dry forests," in Seasonally Dry Tropical Forests, S. H. Bullock, H. A. Mooney, and E. Medina, Eds., pp. 146-194, Cambridge University Press, New York, NY, USA, 1995.

[34] R. K. Chaturvedi, Plant functional traits in dry deciduous forests of India, Ph.D. thesis, Banaras Hindu University, Varanasi, India, 2010.

[35] J. A. Ratter, "Transition between cerradão and forest vegetation in Brazil," in Nature and Dynamics of Forest-Savanna Boundaries, P. A. Furley, J. Proctor, and J. A. Ratter, Eds., pp. 417-429, Chapman and Hall, London, UK, 1992.

[36] S. I. Aiba and K. Kitayama, "Structure, composition and species diversity in an altitude-substrate matrix of rain forest tree communities on Mount Kinabalu, Borneo," Plant Ecology, vol. 140, no. 2, pp. 139-157, 1999.

[37] N. Ayyappan and N. Parthasarathy, "Biodiversity inventory of trees in a large-scale permanent plot of tropical evergreen forest at Varagalaiar, Anamalais, Western Ghats, India," Biodiversity and Conservation, vol. 8, no. 11, pp. 1533-1554, 1999.

[38] T. W. Gillespie, A. Grijalva, and C. N. Farris, "Diversity, composition, and structure of tropical dry forests in Central America," Plant Ecology, vol. 147, no. 1, pp. 37-47, 2000.

[39] P. S. Swamy, S. M. Sundarapandian, P. Chandrasekar, and S. Chandrasekaran, "Plant species diversity and tree population structure of a humid tropical forest in Tamil Nadu, India," Biodiversity and Conservation, vol. 9, no. 12, pp. 1643-1669, 2000.
[40] W. Huang, V. Pohjonen, S. Johansson, M. Nashanda, M. I. L. Katigula, and O. Luukkanen, "Species diversity, forest structure and species composition in Tanzanian tropical forests," Forest Ecology and Management, vol. 173, no. 1-3, pp. 11-24, 2003.

[41] F. Q. Brearley, S. Prajadinata, P. S. Kidd, J. Proctor, and Suriantata, "Structure and floristics of an old secondary rain forest in Central Kalimantan, Indonesia, and a comparison with adjacent primary forest," Forest Ecology and Management, vol. 195, no. 3, pp. 385-397, 2004.

[42] A. H. Gentry, "Changes in plant community diversity and floristic composition on environmental and geographic gradients," Annals of Missouri Botanical Garden, vol. 75, pp. 1-34, 1988.

[43] R. Valencia, H. Balslev, and C. G. Paz y Mino, "High tree alpha-diversity in Amazonian Ecuador," Biodiversity and Conservation, vol. 3, no. 1, pp. 21-28, 1994.

[44] N. Top, N. Mizoue, S. Ito, S. Kai, T. Nakao, and S. Ty, "Effects of population density on forest structure and species richness and diversity of trees in Kampong Thom Province, Cambodia," Biodiversity and Conservation, vol. 18, no. 3, pp. 717-738, 2009.

[45] R. Sagar, A. S. Raghubanshi, and J. S. Singh, "Tree species composition, dispersion and diversity along a disturbance gradient in a dry tropical forest region of India," Forest Ecology and Management, vol. 186, no. 1-3, pp. 61-71, 2003.

[46] R. Condit, P. S. Ashton, P. Baker et al., "Spatial patterns in the distribution of tropical tree species," Science, vol. 288, no. 5470, pp. 1414-1418, 2000.

[47] K. M. Kochummen, J. V. Lafrankie, and N. Manokaran, "Floristic composition of Pasoh Forest Reserve, A lowland rain forest in Malaysia," Journal of Tropical Forest Science, vol. 3, no. 1, pp. 1-13, 1990.

[48] R. Condit, S. P. Hubbell, J. V. Lafrankie et al., "Species-area and species-individual relationships for tropical trees: a comparison of three 50-ha plots," Journal of Ecology, vol. 84, no. 4, pp. 549-562, 1996.

[49] I. Backéus, B. Pettersson, L. Strömquist, and C. Ruffo, "Tree communities and structural dynamics in miombo (Brachystegia-Julbernardia) woodland, Tanzania," Forest Ecology and Management, vol. 230, no. 1-3, pp. 171-178, 2006.

[50] C. V. Chittibabu and N. Parthasarathy, "Attenuated tree species diversity in human-impacted tropical evergreen forest sites at Kolli hills, Eastern Ghats, India," Biodiversity and Conservation, vol. 9, no. 11, pp. 1493-1519, 2000.

[51] R. Sagar and J. S. Singh, "Tree density, basal area and species diversity in a disturbed dry tropical forest of northern India: implications for conservation," Environmental Conservation, vol. 33, no. 3, pp. 256-262, 2006.

[52] R. S. Singh, S. C. Srivastava, A. S. Raghubanshi, J. S. Singh, and S. P. Singh, "Microbial C, N and P in dry tropical savanna: effects of burning and grazing," Journal of Applied Ecology, vol. 28, no. 3, pp. 869-878, 1991.

[53] R. Sagar, A. S. Raghubanshi, and J. S. Singh, "Comparison of community composition and species diversity of understorey and overstorey tree species in a dry tropical forest of northern India," Journal of Environmental Management, vol. 88, no. 4, pp. 1037-1046, 2008.

[54] A. S. Raghubanshi and A. Tripathi, "Effect of disturbance, habitat fragmentation and alien invasive plants on floral diversity in dry tropical forests of Vindhyan highland: a review," Tropical Ecology, vol. 50, no. 1, pp. 57-69, 2009. 
[55] N. D. Martijena and S. H. Bullock, "Monospecific dominance of a tropical deciduous forest in Mexico," Journal of Biogeography, vol. 21, no. 1, pp. 63-74, 1994.

[56] D. B. Clark, D. A. Clark, and J. M. Read, "Edaphic variation and the mesoscale distribution of tree species in a neotropical rain forest," Journal of Ecology, vol. 86, no. 1, pp. 101-112, 1998.

[57] J. G. Pausas and M. P. Austin, "Patterns of plant species richness in relation to different environments: an appraisal," Journal of Vegetation Science, vol. 12, no. 2, pp. 153-166, 2001.

[58] S. E. Russo, S. J. Davies, D. A. King, and S. Tan, "Soil-related performance variation and distributions of tree species in a Bornean rain forest," Journal of Ecology, vol. 93, no. 5, pp. 879889, 2005. 

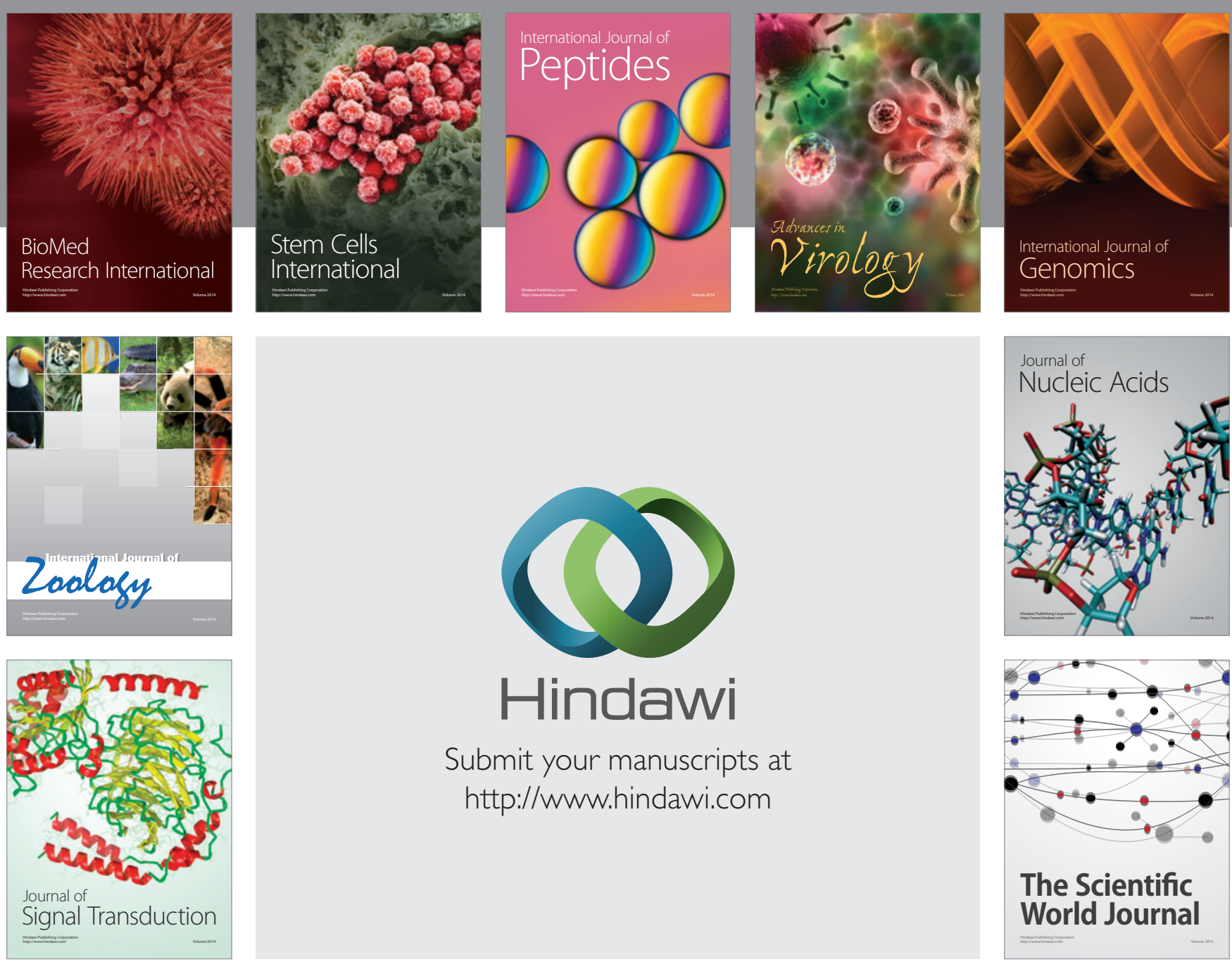

Submit your manuscripts at

http://www.hindawi.com
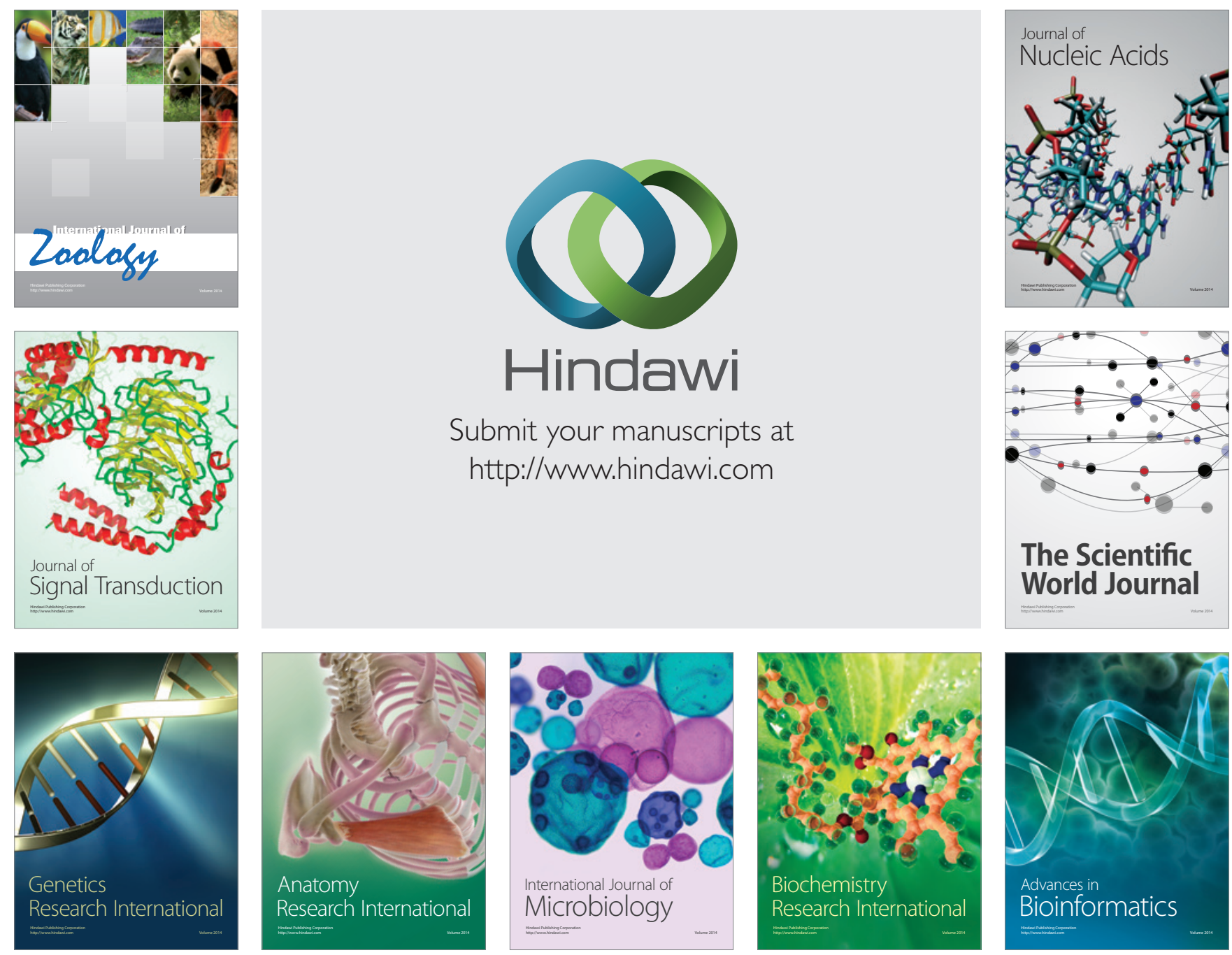

The Scientific World Journal
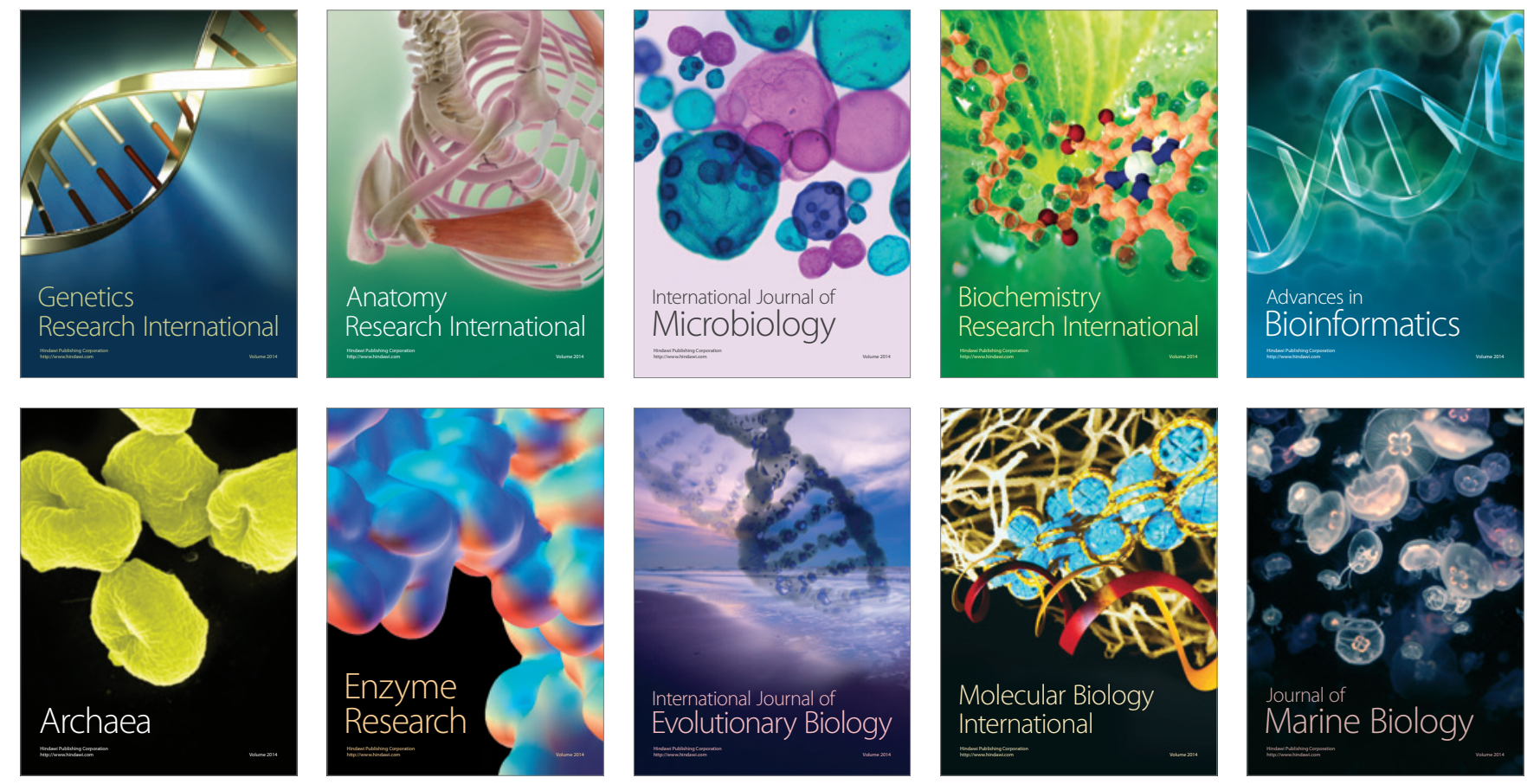